\title{
連結式容器交換ロボットの開発
}

$\begin{array}{lllllllll}\text { 関 } & \text { 淳 也*1 } & \text { 青 山 } & & \text { 元 }^{* 1} & \text { 石 } & \text { 和 } & \text { 良*1 } \\ \text { 石 村 } & \text { 左緒里*1 } & \text { 和田迫 } & \text { 鉄 } & \text { 矢*1 } & \text { 薩 } & \text { 見 } & \text { 雄 } & \text { 一 } \\ \text { 横 田 } & \text { 和 隆 } * 2 & \text { 尾 崎 } & \text { 功 } & \text { 一 } & \text { 山 } & \text { 本 } & \text { 純 } & \text { 雄 } * 3\end{array}$

\section{Development of an Autonomous Robot System Towing the Medecine Container}

\author{
Junya Seki*1, Hajime Aoyama*1, Kazuyoshi Ishikawa*1, Saori Ishimura*1, \\ Tetsuya Wadasako*1, Yuichi Satsumi*1, Kazutaka Yokota*2, \\ Koichi Ozaki² and Sumio Yamamoto*3
}

\begin{abstract}
We have developed an autonomous robot carrying a heavy medicine container, to be used in the medicine factory. In this environment, its workspace is narrow and the robot has to negotiate between existing machines and instruments. It is also necessary for the robot to comply with strict GMP standards defined by Ministry of Health, Labour and Welfare, Japan for medicine production. The robot tows an empty container to the throw-in platform according to the instruction given by the process controller system via infrared communication. Once loaded, the container is again towed by the robot and stored at a designated position in the stowage area. The robot runs on magnetic rails autonomously and is able to tow a container weighing $200[\mathrm{~kg}]$, or heavier, and precisely position the container at the specified location with less than $10[\mathrm{~mm}]$ of error. The container is rigidly held by a specifically designed gripper on the robot during transportation to maintain precise motion and positioning of the container. Three robots have worked in a medicine factory for more than two years without causing a single interruption in the manufacturing process, achieving improved production efficiency, lowered production costs, with fewer workers attending the production line than before.
\end{abstract}

Key Words: Container Transportation, Robot, Medicine Factory, Connection Mechanism

\section{1.はじめに}

医薬品業界は, 日米 EU 医薬品規制調和国際会議（ICH）に よる国際標準化が進む中で, より高い品質 (薬効, 安全性) へ の要求の増大や, 新薬開発費用の上昇および薬価改定などに伴 う利益減少によるコスト競争の激化といった厳しい環境下にあ る.さらに，日本の伝統と文化である漢方薬が医療用として認 められ, 国際展開が進んでおり, 国際競争力の強化が必要になっ ている。

製薬会社における製造ラインでは, 品質保証の観点より原料 や製品の搬送をバッチ単位で行う考え方が多く，そのためにス テンレス製の大型容器を用いた搬送が行われている。このよう

原稿受付 2007 年 12 月 14 日

*1富士重工業株式会社

$* 2$ 宇都宮大学大学院工学研究科

$* 3$ 宇都宮大学

${ }^{* 1}$ Fuji Heavy Industries Ltd.

${ }^{* 2}$ Graduate School of Engineering, Utsunomiya University

${ }^{* 3}$ Utsunomiya University

本論文は有用性で評価されました.
な重量物搬送作業は作業者の肉体的負担となっており, 高齢化 が進む中で作業環境の改善が課題となっている. 国際競争力向 上に最も重要なコスト競争に打ち勝つためには, 製造ラインの 無人化少人化製造の実現, 製造コストの低減を図る必要がある. また少人化を進めることは, 少子高齢化による将来的な労働力 不足に対応することにもなる.

これまでに我々は，清掃ロボットによるビルの清掃システム および広域清掃システムを開発し，床面を自走しながら清掃す るロボットを実用化している $[1] 〜[3]$. そこで，この清掃ロボッ 卜を応用し, 医薬品製造ラインにおける容器台車を連結し衰引 走行して搬送するロボットを開発し, 医薬品製造ラインに導入 することとした $[4] 〜[6]$.

本稿では，まず製薬ラインの容器交換作業について考察し, 要 求仕様を明確にする。 そして, 要求仕様を満たす実用的な容器 交換ロボットの設計方針, 機構, 走行性能, 安全性設計につい て述べる。 


\section{2. ロボットによる容器交換作業}

\section{1 作業環境}

製薬工場では, 薬品そのものの製造, 製造した薬品の専用容 器への投入, 出荷用の梱包といった工程がある。この中で薬品 を容器に投入する工程は造粒工程とも呼ばれ，Fig. 1 のような 製造室で行われる。この工程では, 空の容器を台車で製造室内 の薬品投入台まで運び, 薬品充填後に所定の場所へ容器を運ぶ 作業が必要である. 薬品容器㧍よび投入台の外観を Fig. 2 に, 容器台車の外観を Fig. 3 に示す. 投入台には, 容器を投入口に 確実に位置決めするために両側にガイドが備え付けられている. 容器が設置されると, 上部から規定量の薬品が投入される。台 車車輪は 4 輪とも自在キャス夕となっているため, 抵抗が少な くスムーズに方向転換できる.しかし, 薬品を充填した容器拉よ び台車は重量物であり，その交換作業は Fig. 4 のように人手に よって行われ, 作業効率上の大きな問題で, かつこのような単純 作業に労働力を費やすことも望ましくない. そこで造粒工程に おける容器の交換作業を, 自動化, 省力化することが望まれる。

医薬品製造ラインに関しては, GMP (Good Manufacturing

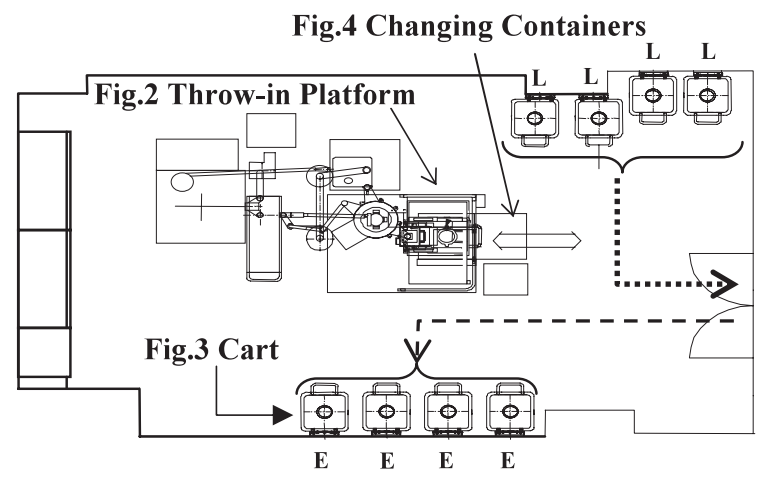

E : Empty Container L : Loaded Container

Fig. 1 Medicine product line

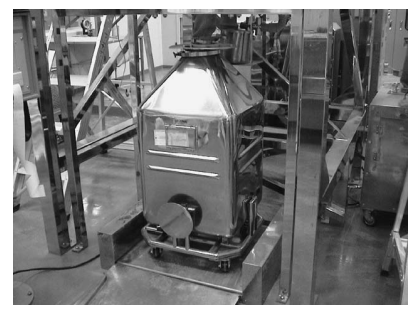

Fig. 2 Medicine container at throw-in platform

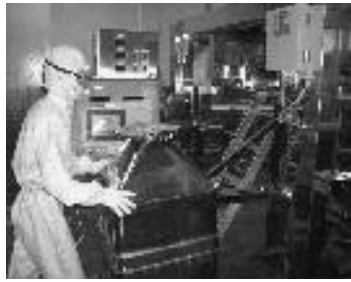

Fig. 4 Changing containers by hand
Practice）による規定があり，導入する搬送方式，搬送装置は この規定を満たす必要がある. GMP とは, 厚生労働省より公 布された医薬品㧍よび医薬部外品の製造管理および品質管理規 則であり，

・人間による間違いを最小限にする

・医薬品の污染, 品質低下を防ぐ

・高い品質を保つ仕組みをつくる

ことを目的としている $[7]$. 現在では, GMP 体制が整っている ことが製造業の許可を取得するための必要要件になっている。 そのため空気の污染を防ぐ設備, 製造室内への立入制限などが 定められており, 高いクリーン度が要求されるため, 製造室は コンパクトに作られることが多い，ただし，造粒工程の製造室 に求められるクリーン度は, 例えば半導体製造に扔けるクリー ン・ルームょりは制約がゆるく, 実際造粒の粉が空気中や床面 には存在する.

室内の粉粒については，以下の点に対する配慮が必要である。

·環境内での装置, 機器類からの, 部品や塗装片などの異物 の落下, 容器への混入

·装置, 機器類への粉粒の付着, 残留

·装置, 機器類に残留した粉粒による装置, 機器自体の腐敗

·装置, 機器類に残留した粉粒の他所への落下, 飛散

- 装置, 機器類に残留した粉粒と, さらなる別の粉粒の付着, 混合による化学反応の発生

また今日の医薬品の製造に扔いては，同じ製造ライン上で多 品種の薬品をバッチ単位で製造することが多く, ラインそのも のの設備更新や変更はまれにしか行われないのが現状である. このことは自動搬送装置の導入による効率化，省力化を考える 際に, 既存製造設備側の大幅な整備や更新を求めることが難し いことを意味し, 既存設備に極力変更を加えることなく, 容器 搬送装置の導入ができることが望ましい．

工場環境における搬送方法としては，AGV，コンベア方式， 自動リフトなどや [7]〜 [14]，クレーン [15] がある.クリーン． ルームの無人化製造としては, 半導体工場で $\mathrm{AGV}$ が使用され ている事例があるが, 製造室のスペース, 設備レイアウトの変更 などの大幅な環境整備が必要であり, 医薬品製造現場への AGV 等の大型搬送機構を導入することは困難と言わざるをえない. ローラコンベアなどは，据付固定によるフロア常設になるため, 柔軟性に欠け，人動線や物流動線が分断され，製造室内の清掃 性が悪くなりクリーン度の低下を招く。またクレーンは効率性 と柔軟性の面で比較的優れているが，搬送物体の把持や位置決 め時, 人による操作が必要となるため, 完全自動化に適してい ない [14].

したがって, 既存の設備に大幅な変更を加えることなく容器 の交換作業を自動化無人化するためには，小型で旋回半径が小 さく，製造室内を自由に移動できる搬送ロボットの開発が有効 であると考える。このような搬送ロボットを製造ラインの中に システムとして組み込むことで，狭い製造エリアを有効活用で き, 必要なクリーン度を維持した上で, 作業負荷低減と作業効 率の向上を実現できると考えられる。

\section{2 要求仕様}

本システムは，既存の医薬品製造室において，連結式容器搬 
送ロボットが自動で医薬品の充填容器を交換するシステムであ る.製造ラインの無人化のためには, 製造設備と連動してロボッ トが動作し, 効率よく容器を搬送する必要がある. 以下に本口 ボットを医薬品製造ラインで稼動するために課せられた要求仕 様を示す。

（1）既存の設備レイアウトを変更せずに，狭い製造室内を自律 移動できること。

(2) 従来の薬品容器を使用でき, 移載のために追加の設備を要 さないこと. 薬品投入時に支障が出ない位置決め精度を持 つこと.

（3）製薬工場の GMP に適合すること.

（4）無人化, 少人化製造を実現すること. 高安定稼動であり, 誤 動作により製造ラインを停止させることがないこと．

（5）作業者との共存を考慮した安全性を確保すること.

\section{3. 連結式容器交換ロボットの開発}

\section{1 技術的課題}

前章までに述べた要求仕様に対する技術的課題を以下に示す.

（1）製造室内で他の機器と接触することなく移動できるよう，小 型車体で旋回半径が小さいこと。

（2）重量物である薬品容器を, 移載装置を必要とせずに簡便に 移送できること．なお， 8.1 節で述べる導入事例では, 薬品 充填時の容器重量は $200[\mathrm{~kg}]$ である.

（3）薬品容器の設置精度 $\pm 10[\mathrm{~mm}]$ 以内を実現すること.

（4）GMPに適合し，製造室内の環境を污染しないこと.

（5）既存設備と通信によって連動し，設備側の指示に従って決 められた経路を自律走行して，人手を介することなく容器 交換作業が行えること.

（6）機械的な故障，破損がなく，ノイズなどに耐性があること

（7）作業者に衝突，接触することなく自律走行できること.た だし製造室は GMP の規定から，設備や壁面が鏡面仕上と なっているため，これらの固定物を障害物と誤認識しない こと.

本ロボットシステムは，実環境における運用を目的としてい るため, コスト低減と信頼性, 耐久性などの品質を考慮して, 筆 者らがすでに実用化に成功している清掃ロボットと，車体構造， 足回りなどを共有化することとした。 さらに上記課題の達成に 適した，信頼性が高く低コストな既存技術は積極的に用いる。

\section{2 外観および仕様}

開発したロボットの外観を Fig. 5 に，仕様を Table 1 に示 す。本ロボットは製薬ライン内で容器と連結し, 自走しながら 交換作業を行う。システムは，メイン・コントローラ，操作パネ ル・コントローラ, モータ・コントローラから構成される分散シ ステムであり，各コントローラ間は，シリアル通信 $(\mathrm{RS}-232 \mathrm{C})$ でつながれている。他の機器は，メイン・コントローラにパラ レル I/O で接続されている. 足回りは, 左右 2 輪と後部キャス 夕 1 輪から成る 3 点接地で, 左右 2 輪が駆動輪となっている. 走行誘導センサとして前後に磁気ガイド・センサを搭載し, 前 進, 後進が可能である. 安全装置としてレーザ式の測域センサ, バンパセンサを搭載し, ユーザインターフェースとして 12.1 型 のタッチパネルを搭載している。このタッチパネルは, 対話式

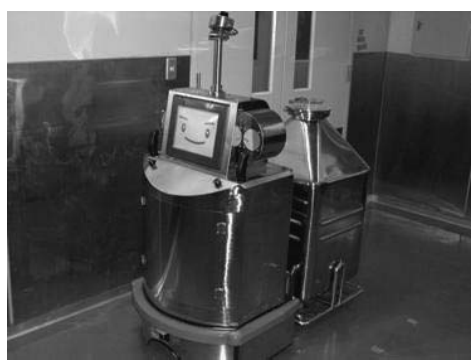

Fig. 5 Appearance of the developed robot

Table 1 Specification

\begin{tabular}{|l|l|}
\hline Length & $646[\mathrm{~mm}]$ \\
\hline Width & $744[\mathrm{~mm}]$ \\
\hline \multirow{2}{*}{ Height } & $1600[\mathrm{~mm}]$ (Laser range finder) \\
& $1268[\mathrm{~mm}]$ (Touch panel) \\
\hline Weight & $125[\mathrm{~kg}]$ (including counter weight) \\
& $170[\mathrm{~kg}]$ (with battery) \\
\hline Velocity & $5[\mathrm{~m} / \mathrm{min}], 10[\mathrm{~m} / \mathrm{min}]$, 2level \\
\hline Drive & DC servo motor $(100[\mathrm{~W}]) \times 2$ \\
\hline Battery & $65[\mathrm{Ah}] \times 2$ \\
\hline Working time & $6[\mathrm{H}]$ \\
\hline Payload & $400[\mathrm{~kg}]$ maximum \\
\hline
\end{tabular}

に操作できるようになっており，またロボットの状態も人の顔 をイメージした表情と共に表示される．Fig. 6 にシステム図を 示す. また Fig. 7 に各機器の配置と容器台車, ロボットが容器 を運搬するときの全長を示す、ロボットは, この容器台車と連 結した状態で，導入製造室内の通路を走行できるよう寸法が決 められた。すなわちロボットの占める床面面積は作業者が容器 台車を推して作業する際に人間が占める面積とほぼ同等である ようになっている。

\section{3 車体および足回り}

本ロボットは, 医薬品を扱うラインで稼動するため, GMPに したがって車体はすべてステンレス製となっており，表面はバ フ４00 仕上げの無塗装とし, カバーは粉粒が堆積・残留しな いよう，Fig. 8 のように車体各部に鋭利な部分がない丸みを持 たせた形状とした。ささらに粉粒が付着したとしてもロボット内 部に入り込まないように，隙間は線溶接で埋められている.

製造室の床面は, 摩擦の小さいエポキシ樹脂性の塗料が塗布 されており，さらに非常に微小な医薬品の粉塵が発生して床面 に付着する場合があり, 走行中の駆動輪に滑りが生じる危険性 がある、そこでタイヤ幅を狭くし，タイヤゴムの硬度を下げる ことで，グリップの向上を図り，滑りの発生を防ぐこととした。 またメンテナンス性の向上および製造室内へのボルト脱落防止 のため，ボルト本数を極力減らし，かつ使用する場合にはフラ ンジ・ボルトを採用している。 さらに, 車体フレーム, 足回り, 制御装置, 駆動モータ, センサ, ハーネス, その他艤装部品な どは, 実用化済の清掃ロボットと共有化し, 開発コスト, 製造 コストを抑え，信頼性や耐久性などの品質を確保した 6$]$.

\section{4 連結機構}

容器の移送方式としては, パレット方式やトレーラ方式など が考えられる。パレット方式は容器の移載装置が必要となり, 設 


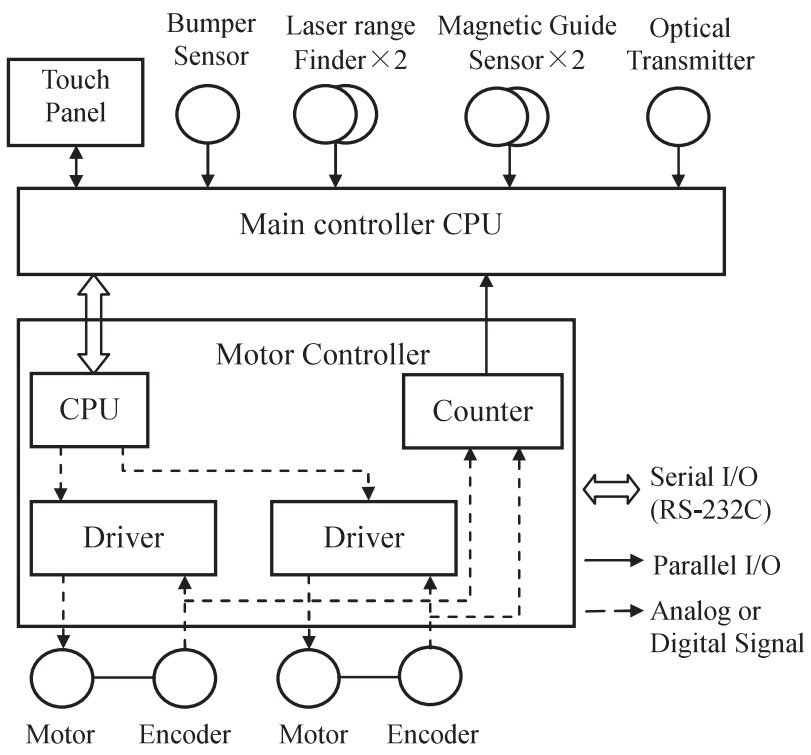

Fig. 6 System
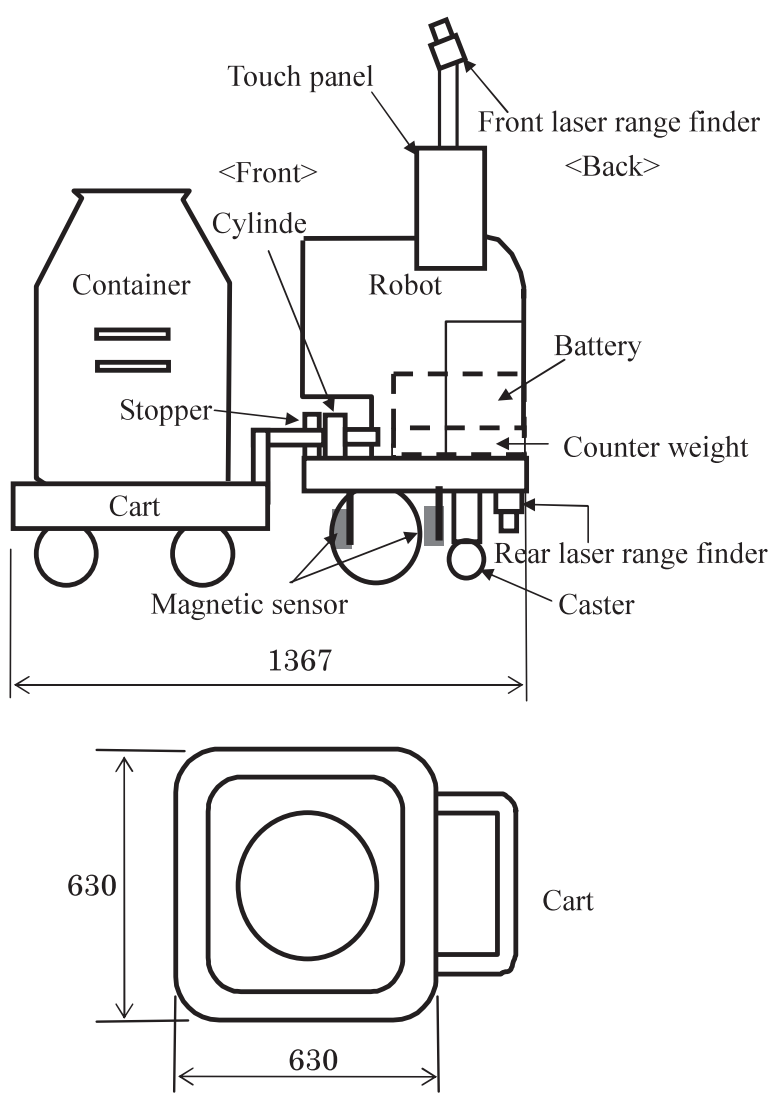

Fig. 7 Configuration

備の追加を要するため適当ではない．またトレーラ方式の連結 では, 方向転換時にジャックナイフ現象などが生じるため, 切 り換しのような複雑な制御とスペースが必要となるため, 作業 環境が限られている製薬ラインには適さない。そこでロボット と容器をストッパで 2 点固定し, 一つの剛体として一体化して, 連結中は常に同じ位置関係を保つ連結方式を用いることとした。

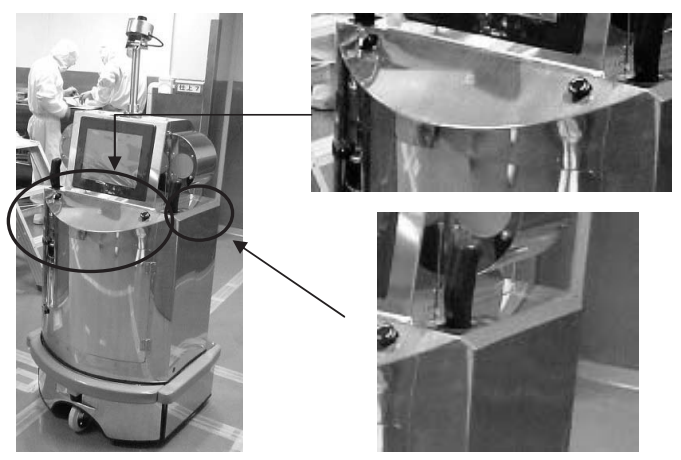

Fig. 8 Shape of body

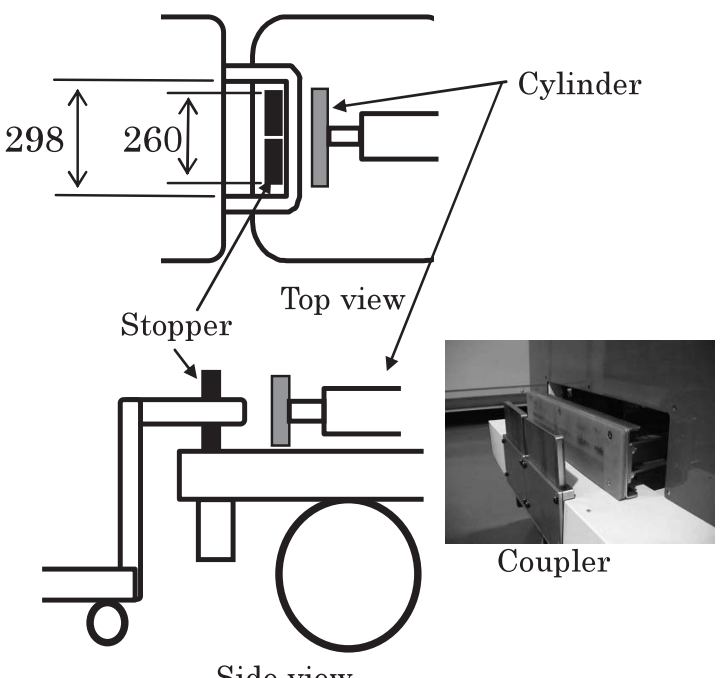

Fig. 9 Coupler

このとき容器の設置精度を確保するためには, 連結時に容器と ロボットの位置関係に偏差が生じても修正する仕組みが必要で ある。

連結時の偏差の修正には，左右前後方向にアクチュエータを 設け位置を矯正する方法も考えられるが，連結部が大型になり， 製造コストの問題や電力消費量の増加により稼働時間が短縮す るなどの問題が考えられるため，実用的ではない．また連結お よび解放に要する時間が延びることで作業効率の低下すること も考えられる。そこで，(1）低電力，（2）短い連結時間，(3) 低故障率，（4）高い容器の設置精度の確保，（5）移動ロボット に搭載できる，といった条件を考慮し，Fig. 9 のような連結機 構を設計した。

本機構は，二つの上下に動作するストッパと前後に伸縮する 電動シリンダにて, 台車の取手を挟み込んで固定する。この取 手は人手による容器交換作業の際には存在せず，今回ロボット との連結用にあらたに台車に付加したものである．Fig. 10 に 上下ストッパの構造を示す。ストッパはカム機構となっており, アクチュエータとリミット・スイッチにより上下する。電動シリ ンダは, 容器台車との連結に十分な推力を持つものを選定した。 電動シリンダの推力と, 連結に要する押し付け力を Table 2 に 示す. Table 2 中の勾配 5.2 [deg] は, 本ロボットが稼動する環 


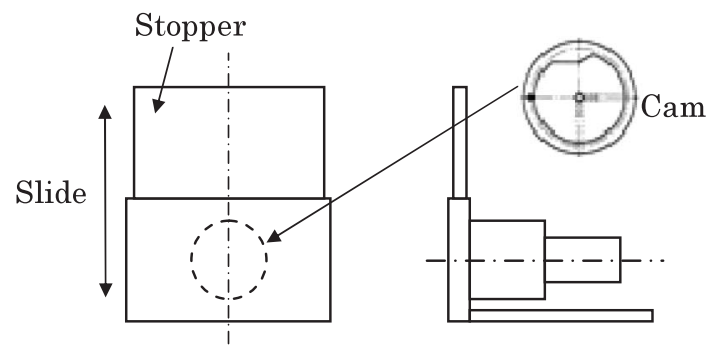

Fig. 10 Structure of stopper

Table 2 Actuator strength

\begin{tabular}{|c|c|}
\hline Cylinder & $392[\mathrm{~N}]$ \\
\hline Necessary Actuator Strength on the Flat Surface & $53.9[\mathrm{~N}]$ \\
\hline Necessary Actuator Strength on the Slope (5.2[deg]) & $176[\mathrm{~N}] \quad$ (Measured) \\
\hline
\end{tabular}

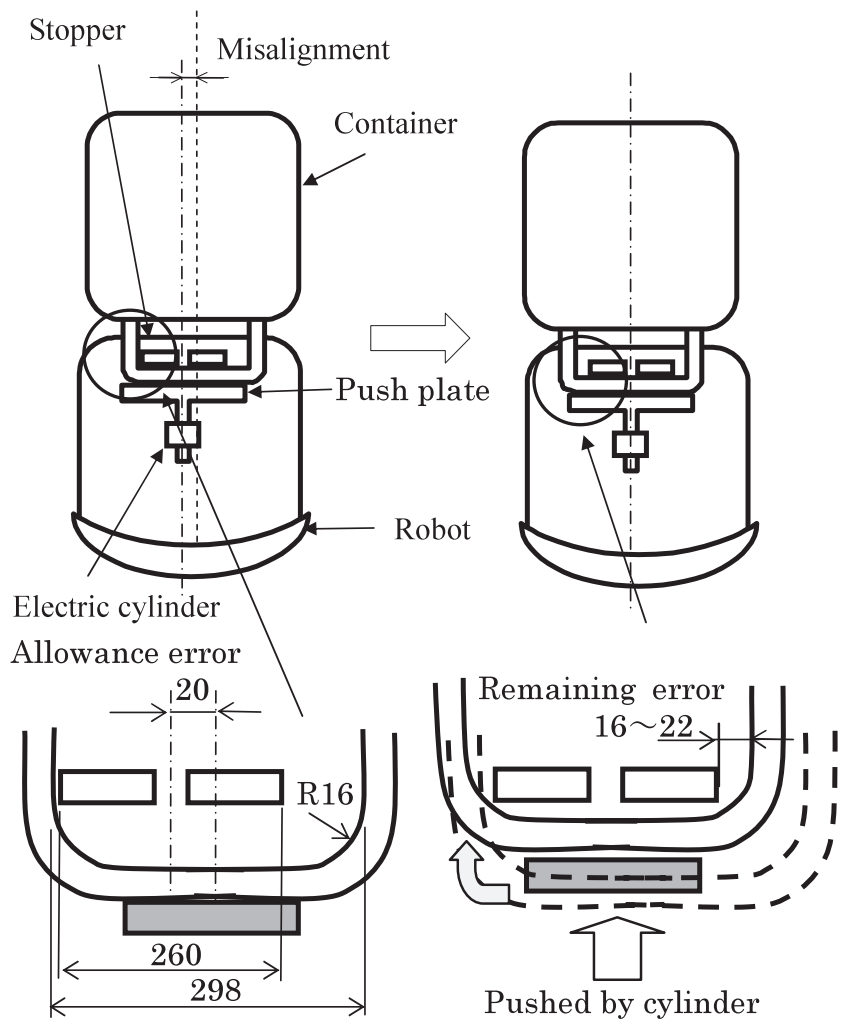

Fig. 11 Slide mechanism along for the coupler

境下で想定される最大勾配である.

連結時のロボットと容器の位置偏差修正のために, 容器台車 の連結部は，ステンレスパイプの曲線形状とした。このステン レスパイプを, ロボット側の上下ストッパと押し板のついた電 動シリンダで押し达んで固定する。連結時にロボットと容器の 相対位置に偏差がある場合，連結部の曲線部にロボットのストッ パが接触し, 容器台車がスライドすることにより, ずれを矯正で きる、容器台車連結部のパイプの曲線形状は, 例えばカム曲線 の応用が考えられるが，本機構では作図により， $\phi 35$ のパイプ を曲げ，R16の円形とした.このようにメカ機構を利用して偏 差を矯正する手法は Selective Compliance（選択的柔軟性）と
呼ばれ，スカラロボットで用いられた位置決め手法である $[16]$. 本連結機構では, 台車の自在キャスタと曲線部により横ずれコ ンプライアンスが大きく, シリンダの押し付けとスライド・レー ル・ガイドの剛性により軸倒れコンプライアンスが小さくなる ため, ロボットと容器台車の中心軸が一致するよう, スライド させることができる．Fig. 11 に示すように，容器台車取手部 の内寸とストッパの幅から, 台車連結時のロボットの横方向の 許容誤差は左右各 $19[\mathrm{~mm}]$ で, 押し付けと曲線部による補正後 の残留誤差は左右各 $16 \sim 22[\mathrm{~mm}]$ となる. なお, 容器台車の取 手と摩擦が小さくなるように, ストッパや電動シリンダの押し 付け部は NCナイロンとした。

\section{4. 走 行 制 御}

\section{1 誘導方法}

本ロボットには，狭い製造室内で他の機器と接触することな く, 信頼性のある走行法が求められる。また製造ライン内では 粉塵が発生するため, 污れに強い誘導法が必要である.

室内でのロボットの誘導法としては, ジャイロ・センサや室 内 GPS を用いた方法等が考えられる。ジャイロ・センサの場 合, 角度のキャリブレーションを行う必要がある。実用化済の 清掃ロボットでは, 磁気テープによるキャリブレーションを行っ ていた。すなわち基準となる向きに平行に磁気テープを設置し, ロボットを磁気テープに沿って走行させ, ある程度の距離を走 行するとロボットは基準方向を向くため, そこでジャイロ・セン サの角度をセットする手法をとっていた。しかし狭い製造室内 では，上記のキャリブレーションが有効となるような十分な長 さの直線経路を確保することは困難である。また室内 GPS は 非常にコストが高く，実用的ではない [17] [18].

そこで本ロボットでは, 磁気レールと磁気ガイド・センサに よる誘導方法に，エンコーダを組み合わせた走行制御を採用し た，走行は磁気誘導によって行う。停止位置では，減速時間を 考慮し, 目標位置手前 $160[\mathrm{~mm}]$ で磁気レールを途切れさせて いる。ロボットは磁気が検出されなくなった地点からオドメト リに基づいて，目標位置に一致するように一定距離走行させる ことで位置決めし停止する。この距離は $100[\mathrm{~mm}]$ 程度となる ため，車輪の滑りなどの影響はほとんど受けない。これはこれ までに多くの AGV や自律移動ロボットで使われている技法で あり，信頼性が高く，実用化に適している。

4.2 磁気によるスピンターン

ロボットの方向転換の方法としては, 磁気レールをカーブ上 に埋め込み，その磁気に沿って進行させる方法が単純であるが, カーブのスペースを確保する必要があり, 狭い製造ラインでは 実現が困難であると考えられる。その他の方法として，ロボッ トの左右の駆動輪を逆回転させるその場旋回（スピンターン） がある。

Fig. 12 に容器連結時にカーブ上に設置された磁気レールに 沿って方向転換した場合を，Fig. 13 にスピンターンした場合 の必要領域を示す。このように，カーブ上に方向転換する場合 は, 内側はロボットの幅, 外側は容器台車幅の分の領域が必要 であり, その分既存の設備から距離を取って磁気レールを設置 しなければならない。、スピンターンによる方向転換では, 必要 


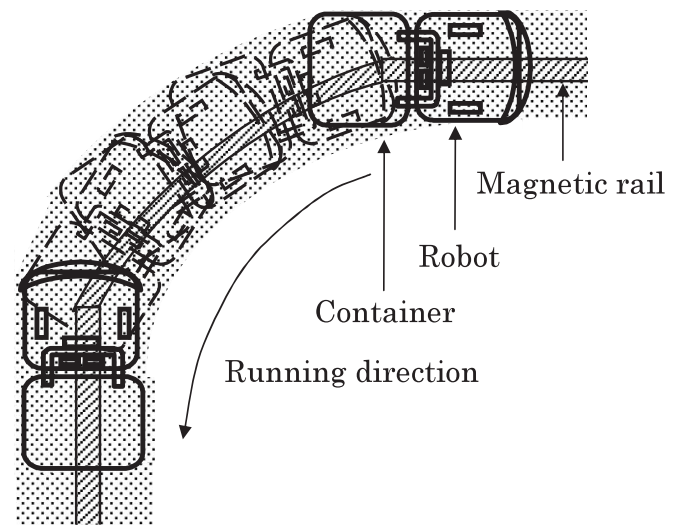

Fig. 12 Running along the curved magnetic rail

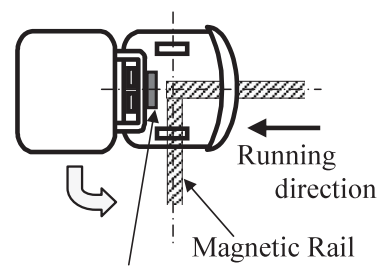

+ Necessary working space

Magnetic Guide Sensor

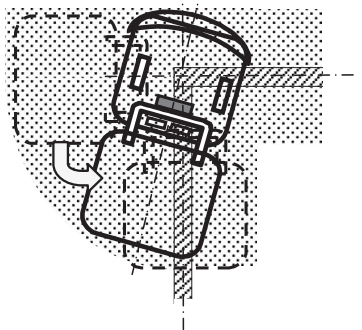

Fig. 13 Spin turn by sensing the magnetic rail

領域は旋回点を中心とし，ロボットと台車が掃引する領域であ る. また通路が限られる製薬室の環境では, 様々な方向から進 入して出ていく交差点を設ける必要が生じる。この場合カーブ 状の方向転換でこれを実現するには, Fig. 14 のように交差点 に複数のカーブを設置せざるをえず，磁気レールの設置に必要 な領域も大きくなる，スピンターンならば，交差点に磁気レー ルを十字に設置することで，あらゆる方向転換が可能となり必 要領域も交差点を中心とした旋回半径分だけである。

よって, 必要領域と磁気レール施工の簡便性から, スピンター ンによる方向転換を用いることとした。本ロボットではジャイ ロ・センサは用いないので. 交差点に十字に施行された磁気レー ルの磁気を, 磁気ガイド・センサで読み取りながら位置決めする.

磁気レールはFig. 15 (1)のような磁場を発して㧍り, 磁気ガ イド・センサはその磁場を測定し, センサの中心と磁気レール 中心の偏差に応じて Fig. 15 (2) のような出力を示し, 磁気レー ルの中心（偏差 0）で $5.0[\mathrm{~V}]$ の出力となる。前述したように, ロボットは交差点にて, 磁気とエンコーダにより位置決めをし て停止する，このときロボットの旋回中心が，交差点中央に一 致するように停止させる. 次に Fig. 13 のように, スピンター ン開始後，方向転換後の磁気レールを検知するまでは一定の速 度で旋回し，検知後は磁気ガイド・センサの出力に応じて，駆 動輪のスピードを比例的に落とし, 旋回レートを徐々に小さく しながらスピンターンを続ける。ささらに磁気ガイド・センサの 出力がセンサ中心に近づいた時点で停止信号を出力することで, 滑らかに停止させる。

本ロボットのスピンターンで問題になるのは，ロボットと容

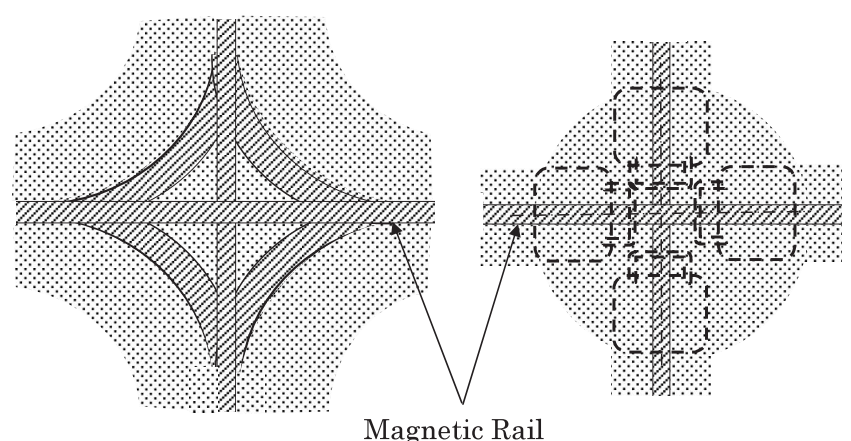

Fig. 14 Necessary working space for turn

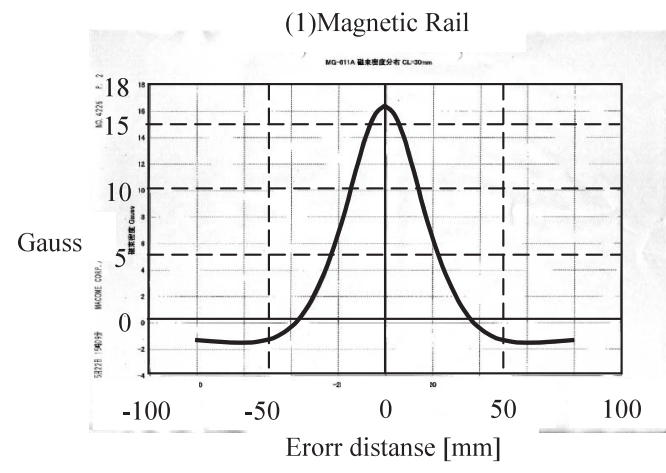

(2)Magnetic Guide Sensor

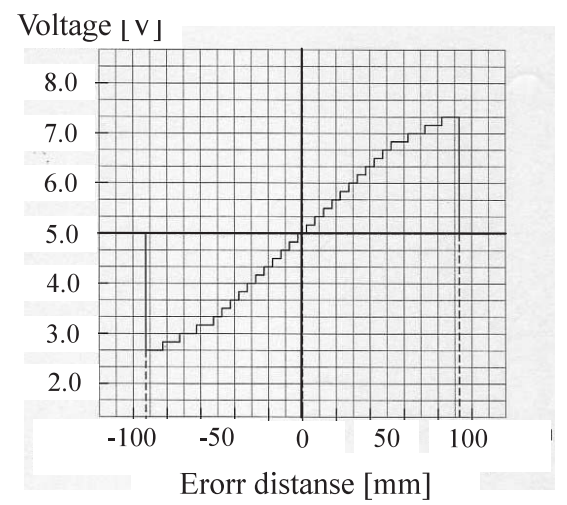

Fig. 15 Output of magnetic rail and guide sensor

器の質量差である。一般にフォークリフトや $\mathrm{AGV}$ 等の搬送機 械では搬送物よりも搬送機械の方が質量が大きいのに対して, 本ロボットでは自重よりも重い容器台車の運搬を想定している. 慣性力を考えると, 搬送機械の質量が大きいほうがスピンター ンが安定し方向精度も確保しやすい。しかし本ロボットでは搬 送物の質量のほうが大きいので, スピンターン時の加減速停止 や線改革速度の指令值の生成に最適力ム曲線を用いて方向精度 を確保した。またロボットにカウンタ・ウエイトを搭載し，口 ボット側の質量を大きくすることで（総重量 $170[\mathrm{~kg}]$ ), 走行, スピンターンの安定性を向上させた。

本手法によるスピンターン終了後の停止位置における, 磁気ガ イド・センサ中心と磁気レール中心の偏差は, 最大で左右 $7[\mathrm{~mm}]$ 程度であった。これは, 本ロボットで採用した磁気センサの不 感帯が $5[\mathrm{~mm}]$ ピッチであるために発生した偏差と考えられる. 

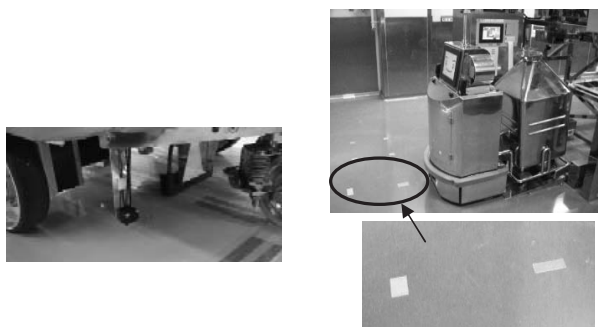

Fig. 16 Color sensor and color marker
実用性の面では, $7[\mathrm{~mm}]$ 程度の偏差は影響なく，スピンターン 後の直進走行も, 経路を逸脱することなく行えるため, 本手法 は実用に耐え得ると考えられる。

\section{3 分岐点の認識}

ロボットは設備から送信される経路指示信号に従い, 複数の 経路のいずれかを走行する。ロボットは経路指示信号に合わせ て，分岐点を識別する必要がある。また分岐点は磁気レールの 途中になるため, 前述した磁気レールの途切れとエンコーダに よる停止位置決めができない.

分岐点の認識方法としては，磁気情報板を床下に埋め込む方 法や, レーザセンサと反射板を組み合わせた自己位置認識など がある. 磁気情報板の場合, 床面との段差ができると粉末や埃 が溜まるため, 平坦にする必要があり, 施工コストが高くなる. また充填容器のような重量物が上を通過した場合, 磁気情報板 の強度が低いため変形する可能性もある、レーザセンサの使用 は, 製造室内の壁や機器がすべてステンレスの研磨材で作られ ていために，反射板と固定物を誤認識する可能性があり信頼性 にそしい.

そこで本ロボットシステムでは，分岐位置に $50[\mathrm{~mm}] \times 100$ $[\mathrm{mm}]$ の色マーカを床面に塗布し, ロボットには色判別が可能な 色センサを装備して, 色によって経路内の位置を認識すること とした. Fig. 16 にロボットに取り付けた色センサと製造ライ ンに塗布した色マーカを示す. 色マーカには, 製薬ラインの床 面にも使われているエポキシ系塗料を用いた。この手法は, 施 工コストが低く床面に影響も与えず，製造室のクリーン度が確 保できるといった利点があり, 製薬工場のインフラとして適し ていると考えられる.

\section{5. 既存製造ラインとの統合}

\section{1 既存システムとの役割分担と連携}

\section{1 .1 既存設備との通信}

移動体の通信方法としては, 無線 LAN が代表的であるが, 安 定性や周囲の設備への影響などの問題がある. 本ロボットシス テムは, 清掃ロボットのエレベータ連動で実績のある光伝送装 置を用いることとした $[2]$. 伝送装置はロボットの待機位置であ るホームポジションと投入台の 2 箇所に設置する。ロボットは, ホームポジションで設備から工程管理デー夕の経路指定信号を 受信する。指定された経路を移動し, 指定の動作を行う。また 動作完了後ホームポジションに戻ると, 動作完了信号を設備に 送信する。

また，投入台への進入時，ロボットは投入台手前で一時停止

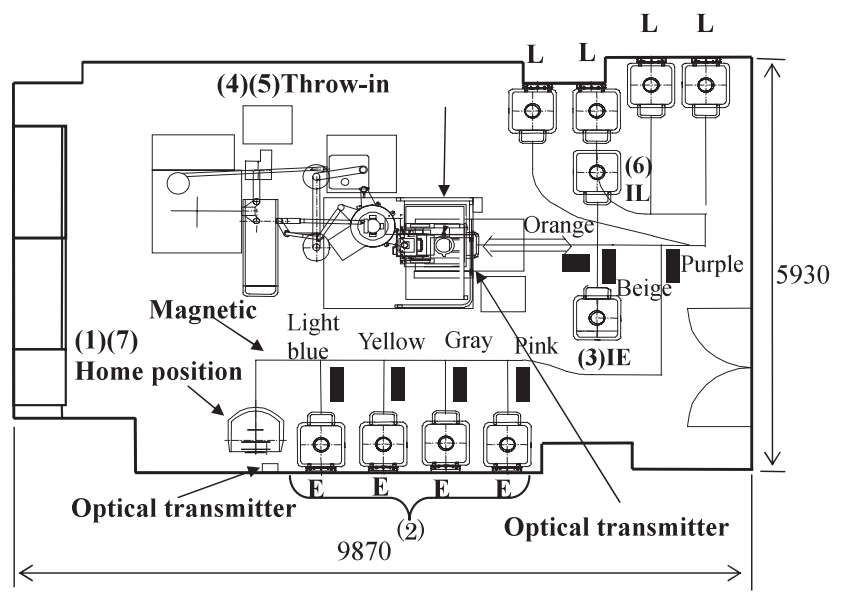

E : Empty Container $\quad$ L : Loaded Container

IE : Intermediate Place of Empty Container

IL : Intermediate Place of Loaded Container

Fig. 17 Layout of the medicine product line

し, 容器交換の可否を, 投入台の前に設置された光伝送装置か ら受信後, 進入する。受信するまでは, 投入台の前で待機し続 ける. 薬品充填を効率的に行うため, 設備は容器の充填完了が 近づいた時点で, ロボットを投入台の前に呼び出し, 充填完了 すると直ちに容器の交換を行わせる.

\section{1 .2 製造室内外の容器の運搬}

これまで述べてきたように，本ロボットは，製造室内におい て容器の交換作業を行う. 製造室内は, 空容器, 実容器の設置位 置が定められている。製造室外から空容器を運んで規定の位置 に置く作業や, 充填完了した実容器を次の工程に移すため, 製 造室外に運び出す作業は，作業者によって行われる.

\section{2 環境構築}

以上の走行制御を考慮し, ロボットを導入する製造室に設置 した磁気レール, 色タグの状態, 容器設置位置を Fig. 17 に示 す. 経路に沿って床面に磁気レールが埋め込まれている.

本製造室には, 投入台の近くに空容器仮設置位置 IE と実容 器仮設置位置 IL がある。これは，投入台での薬品投入に 30 40 分程の時間を要するため, この間にロボットに別な容器を運 ばせ，交換作業を効率的に行うために設けられた位置である。

\section{3 作業手順}

Fig. 18 にロボットの作業手順を示す.

（1）ロボットはホームポジションにて経路指示信号を受信する まで待機する。

（2）指示信号を受信後, 製造室に置かれた空容器 $\mathrm{E}$ と連結する. 連結する空容器は, 経路によって決まっている.

(3) 空容器仮設置位置 IE に, 連結した空容器を設置する.

（4）薬品投入台にて, 薬品を充填された実容器と連結する. 充 填完了は投入台入口の光伝送装置にて設備から通知される.

（5）連結した実容器を実容器仮設置位置 ILに移動し切り離し た後, 空容器仮設置位置 IEに設置していた空容器と再び 連結し，投入台に設置する。

（6）空容器に薬品が投入されている間に, 実容器仮設置位置 IL に設置していた実容器と連結し，実容器設置位置 L に運ぶ. 


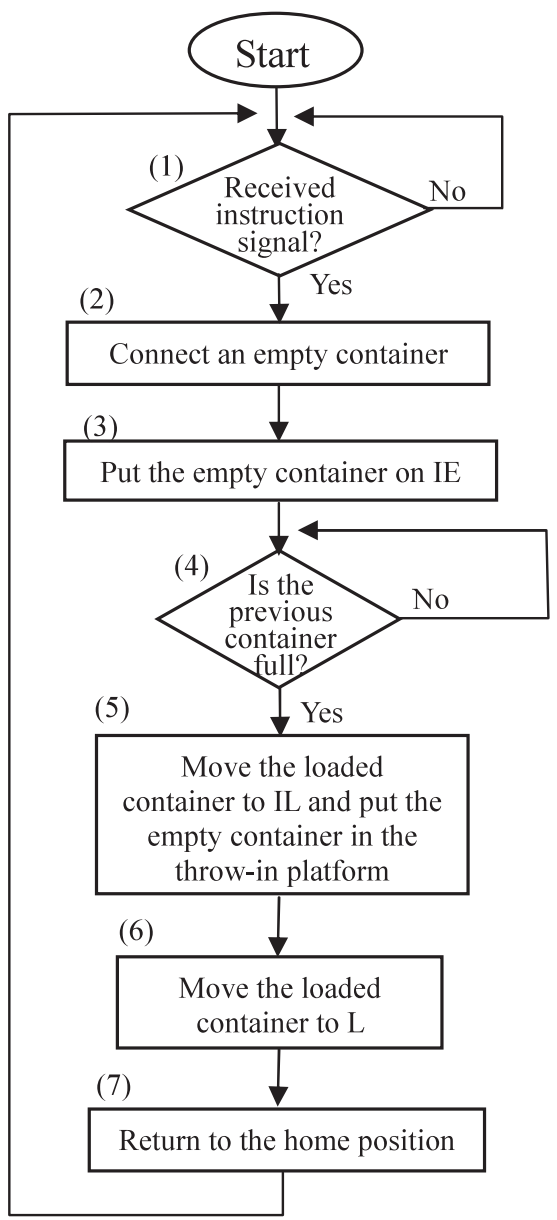

Fig. 18 Flow of actions

設置場所は経路によって決まっている.

（7）ホームポジションに戻り，次の経路指示信号を受けるまで 待機する。

\section{4 ロボット異常発生時の処理}

ロボットが, 何らかの原因で定められた動作と別の行動をす ると，事故や品質悪化につながる抢それがある。本ロボット自 身が検知する異常としては，(1) 経路の逸脱，(2) 経路上の障 害物の出現，(3) バッテリ電圧の低下などがある。これらの異 常を検知した場合，ロボットはただちに停止する。一方，ロボッ トが停止すると製造ラインが停止してしまうので，作業者はす みやかにそのことを知る必要がある。このため, 製造ライン． システムはロボットがホームポジションを出発してからの経過 時間を測定しておう，規定の時間までにロボットが戻らない場 合は異常と判断し, ブザーを鳴らして作業者に知らせる。また ロボット側も前述した異常が発生した場合, 異常の種類に応じ てタッチパネルに表示したり, LEDの点灯により, 作業者に知 らせる機能を有する。

\section{6. 安 全 設 計}

\section{1 レーザ測域センサ}

ロボットの導入により，製造ラインは基本的に無人化される が, 室外との容器の搬出入は作業者が行うので, 衝突を避ける

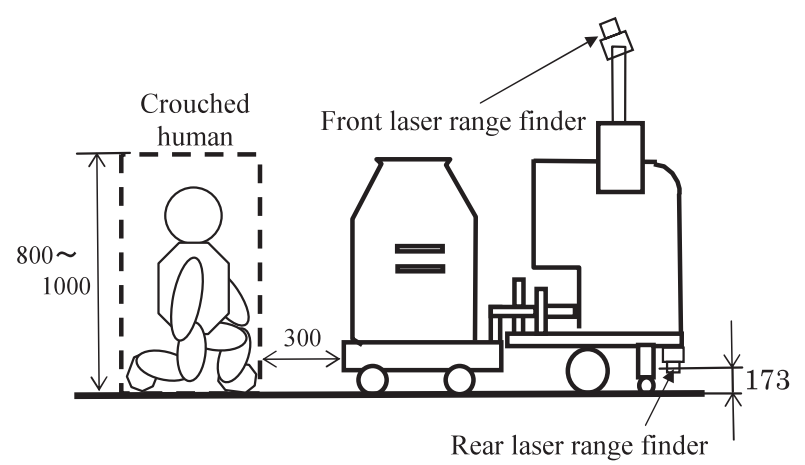

Side view

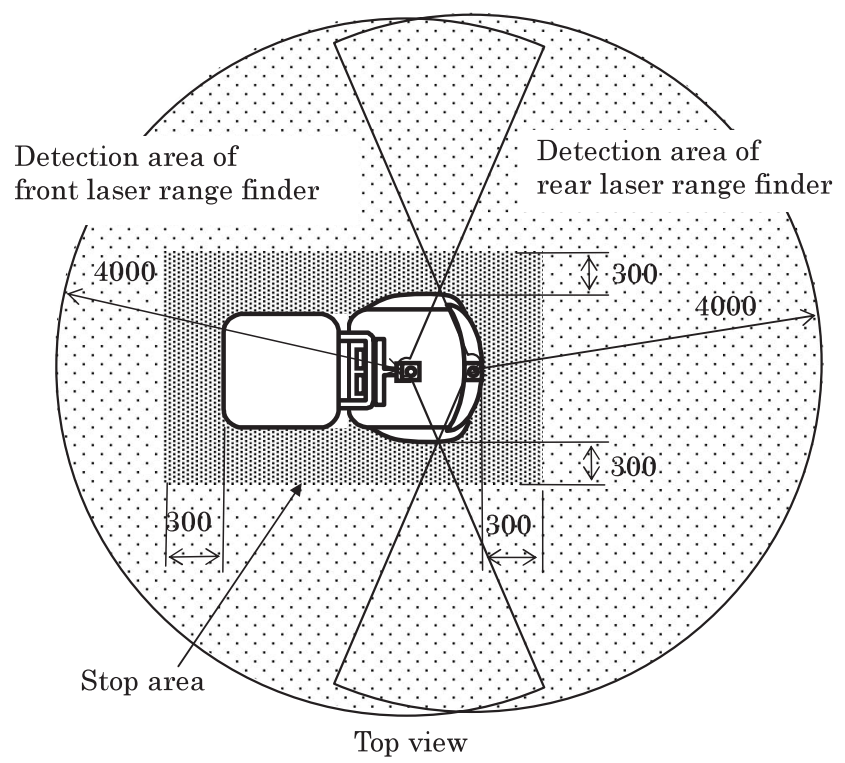

Fig. 19 Detection area of the laser range finder

ための安全対策として，障害物センサが必要である．赤外線等 の反射型センサは, 検知物体の色や材質により, 検知距離に大 きな違いが出ることがある。また製造ラインの設備や壁は鏡面 仕上げのステンレス製であるため, 誤検知の可能性がある。そ こで本ロボットにはレーザ測域センサを搭載することとした。 レーザ測域センサは検知物体の色や材質の影響を受けないため, 物体との距離を正確に測定できる.

Fig. 19 に測域センサの設置位置と検知範囲を示す。製造室内 ではしゃがんで作業する人間がいる場合がある。そこで図のよ うに, 前方測域センサは, 容器を検知せず, 容器から $300[\mathrm{~mm}]$ 離れた位置のしゃがんだ人間（高さ $1[\mathrm{~m}]$ とする）を検知できる 取付位置, 測定範囲とし, 後方測域センサは, 人が横から近づ いたとき，足が巻き込まれる前に停止できる測定範囲としてい る（足のサイズ $300[\mathrm{~mm}]$ 以下とする）。経路上に人や障害物を 検知したときは直ちにロボットを停止させ，安全性を確保する。 またロボットの台車連結側以外の周囲には, ソフトバンパセ ンサを搭載している。 万一人や物体に接触した場合は即座に停 止する．さらに駆動輪周囲にはフットガードを設け，車輪によ る巻き込みを防止する。 


\section{2 ノイズ対策}

実運用においては，ロボットを長時間，作業員の随伴なしに 動作させるために，ノイズ対策を十分に行う必要がある。製造 ラインにおけるノイズ源には，アクチュエータ電源ラインから 生じる電磁気的ノイズと, 照明による光伝送装置に対するノイ ズがある．また，アクチュエータを動作させたときに生じる電圧 変動にも注意する必要がある。今回の実用化に当たっては，ア クチュエータ電源ラインに対しては,アクチュエータおよび各 IC にバリスタ，コンデンサ等を配置しノイズ対策を強化した。 またアクチュエータ動作時に起こる瞬間的な電圧変動に対して は, DC-DC コンバータの設置，バッテリの容量増大により対 応した，光ノイズに対しては，赤外線フィルタを装備すること によって，光伝送装置の誤動作を回避している。これらのノイ ズ対策は，従来から我々の清掃ロボットで採用し実績を重ねて きた技術で，信頼性が高く，実用化には不可欠である。

\section{7. 実 証 試 験}

\section{1 容器台車位置決め試験}

Fig. 20 に示すようにロボットを $5[\mathrm{~m} / \mathrm{min}]$ のスピードで走 行させ，容器台車を押し上げて投入台の規定位置に置き，この ときの容器台車中心 $\mathrm{A}$ 点の $\mathrm{X}$ 方向, $\mathrm{Y}$ 方向の規定位置 $\mathrm{Ar}$ から の偏差を測定する。同時に台車が置かれたときの姿勢を $\theta[\mathrm{deg}]$ とし測定する．以下に試験手順を示す.

（1）磁気レールの切れた位置でロボットの停止信号を出力し, 容 器の規定位置からの偏差および傾きを測定する.

（2）（1）の結果より，停止信号出力位置をプリセットし，容器 設置位置を補正したときの規定位置からの偏差を測定する。 この測定值から，実測と補正によって実現可能な精度を確 認する。

測定はそれぞれ 10 回ずつ行った。
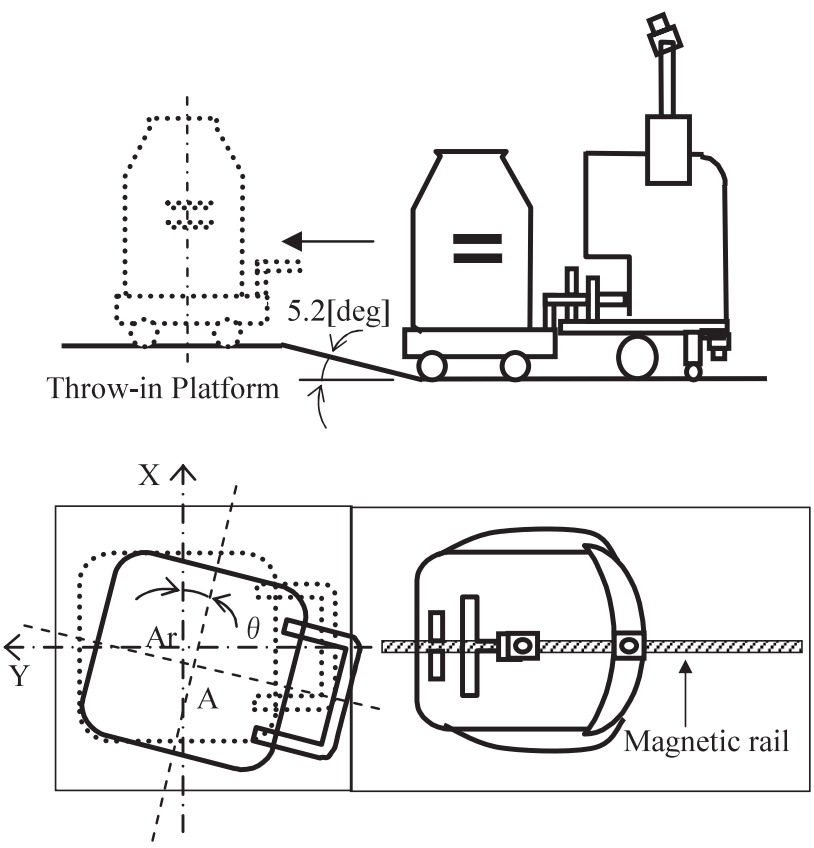

Fig. 20 Positioning experiment

\section{2 試験結果}

（1）では，A 点の測定值は $\mathrm{X}=-5 \sim-2[\mathrm{~mm}], \mathrm{Y}=8$ $12[\mathrm{~mm}]$, 傾きは $1.1 \sim 2.2[\mathrm{deg}]$ であった. X 方向の偏差は $5[\mathrm{~mm}]$ 以内と小さく, 傾きも実用上問題ない範囲であるが, Y 方向の偏差が $10[\mathrm{~mm}]$ 以上とやや大きい. したがって停止信号 出力位置をプリセットすることで, 容器台車をより正確な位置 へ設置することができると考えられる．点 $\mathrm{A}$ の $\mathrm{Y}$ 方向の偏差 の平均值は $9.8[\mathrm{~mm}]$ であった。そこで（2）において，停止信 号位置を $9.8[\mathrm{~mm}]$ 後方へプリセットし, 同様に A 点の偏差と 傾きの測定を行った. Table 3 に測定結果を, Fig. 21 に偏差 の分布を示す.

\section{3 考察}

（2）の結果より，停止信号出力位置をプリセットすることで, 容器の中心と投入台中心の偏差は, X 方向, Y 方向とも $5[\mathrm{~mm}]$ 以内となった. X方向が一側, $\mathrm{Y}$ 方向が+側に偏りがあるが, 技術 的課題である $\pm 10[\mathrm{~mm}]$ 以内を満たしており，台車幅 $630[\mathrm{~mm}]$ に対して $1 \%$ 以下の誤差であるため，実用に十分な精度を実現し ている.よって投入台への容器設置は, 磁気レールが切れてか

Table 3 Result of measurements

\begin{tabular}{|c|c|c|}
\hline & $\mathrm{A}[\mathrm{mm}]$ & $\theta[\mathrm{deg}]$ \\
\hline 1 & $\mathrm{X}=-2, \quad \mathrm{Y}=5$ & 1.2 \\
\hline 2 & $\mathrm{X}=-3, \quad \mathrm{Y}=0$ & 0.5 \\
\hline 3 & $\mathrm{X}=-3, \quad \mathrm{Y}=4$ & 0.4 \\
\hline 4 & $\mathrm{X}=-3, \quad \mathrm{Y}=3$ & 0.8 \\
\hline 5 & $\mathrm{X}=-3, \quad \mathrm{Y}=1$ & 0.2 \\
\hline 6 & $\mathrm{X}=-4, \quad \mathrm{Y}=3$ & 0.6 \\
\hline 7 & $\mathrm{X}=-5, \quad \mathrm{Y}=2$ & 0.8 \\
\hline 8 & $\mathrm{X}=-3, \quad \mathrm{Y}=4$ & 1.1 \\
\hline 9 & $\mathrm{X}=-4, \quad \mathrm{Y}=2$ & 0.2 \\
\hline 10 & $\mathrm{X}=-4, \quad \mathrm{Y}=2$ & 0.5 \\
\hline
\end{tabular}

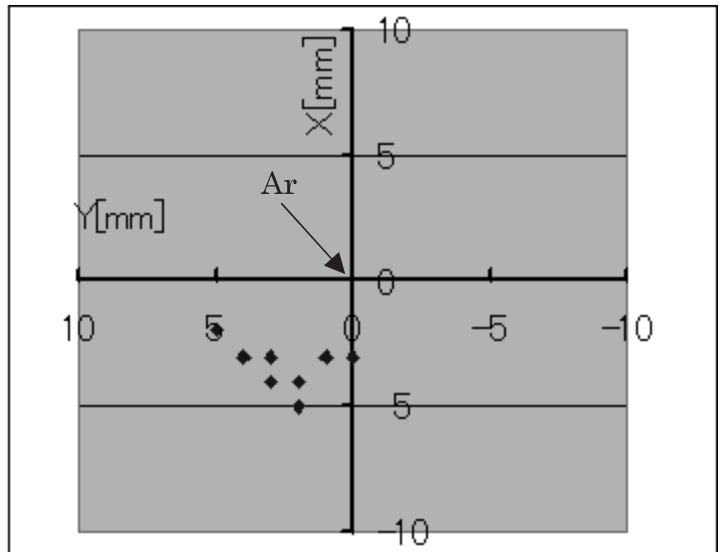

Fig. 21 Distribution of misalignment of the center 

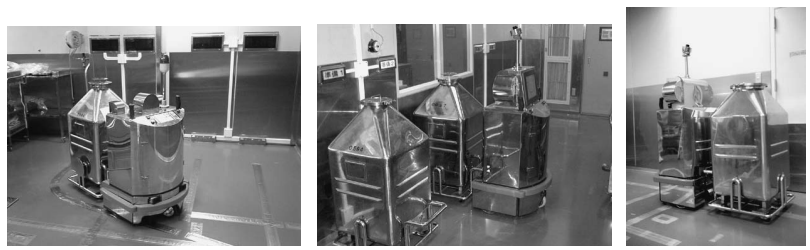

Fig. 22 Installed robots

ら停止する手法で，十分に実用的な精度が実現できるといえる.

\section{8. システムの導入事例と評価}

\section{1 導入事例}

本ロボットを実用化し，株式会社ツムラ静岡工場造粒工程に 導入した．現在 3 台のロボットが三つの製造ラインで，それぞ れ朝 9:00～深夜 3:00 にかけて稼動している (Fig. 22). 作業 者は，ロボットをスタートさせた後は，一定時間ごとの容器の 搬出入と設備からの異常報告に対する対処以外の作業は行って いない. 1 号機を導入してから 2 年以上経過しているが，ロボッ 卜に起因する製造ラインの停止率は $0 \%$ ある。.

\section{2 システムの評価}

導入したシステムは以下の評価を得ている.

（1）製造ラインのレイアウトを変更することなく，製造ライン を自動化できた。導入のためのインフラも, 磁気レールの 設置, 光伝送装置の設置, 色夕グの床面への塗布, 連結用 取手の台車への追加，の最小限に止めた。

（2） 1 回の充電で 1 日分の搬送量をこなすことができるため，口 ボット運用にかかわる作業者の負担が小さい.

（3）これまでは 5 ラインに 5 名の担当者を配置していたが, 本 ロボットの導入により，2 ラインに 1 名の担当者で生産す ることが可能となり，少人化を実現した。

（4）夜間抢よび昼休みにラインの無人稼動が可能となり, 製造 ラインの稼動時間が延び，生産量の増加，製造コストの低 減に貢献することができた。

（5）自動化により作業者の製造ラインへの立入頻度が大きく減 少したため, GMP の適合, 室内空調管理が容易となった。

（6）既存設備システム・ソフトゥェアに変更を加え，ロボット と光伝送装置により通信をすることで, 連動して容器交換 作業を行うとともに, 作業の進行状況, 医薬品の充填状況, 容器搬送回数, ロボットのバッテリ残量等の情報が明確に 確認できるようになった。

\section{9.おわりに}

以下に本論文のまとめを述べる。

（1）既存の医薬品製造設備に大幅な変更を加えることなく, 既 存設備と連動して動作する容器交換ロボットを開発し, 重 量物である充填容器の交換作業を行うシステムを実用化し た。これまで $\mathrm{AGV}$ 等の搬送機械は実用化されているが, 狭い医薬品製造室内での充填容器の運搬㧤よび交換作業を 実現した例は他に類を見ない。
（2）開発したロボットは，GMPに適合し製造室内を污染しない。

（3）製造室内の作業者に対する安全性を確保し，ロボットと人 間の調和を実現しつつ, 安定して長時間稼動し, 容器交換 作業の自動化，無人化を達成した。

（4）以上のように, 医薬品製造ラインでの重量物搬送という, 口 ボットを活用する新たな分野を開拓した。

ロボットを実用化し，作業者に負担のかかる肉体労働を削減し た実績が評価され，経済産業省の「今年のロボット」大賞 2007 の優秀賞を受賞することができた。

今後, 医薬品製造に扔ける造粒工程への本ロボットの導入を 搪大寸るとともに, このロボットを応用し, 造粒工程以外の, 包 装工程, 箱詰めされた薬品の搬送などにも展開していく予定で ある. さらにこの重量物搬送の技術の, 医薬品製造工程以外の, 工場内の搬送, 図書館の本の搬送, 店舗での商品の搬送などの 分野への応用が期待される.

\section{参 考 文 献}

[1] 青山, 田島, 横田, 尾崎, 山本：“自律走行式床面清掃ロボットの開 発”, 日本ロボット学会誌, vol.16, no.1, pp.57-64, 1998.

[2 ] 田島, 青山, 関, 石川, 横田, 尾崎, 山本: “ロボットによる高層ビルの清 掃システムの開発”, 日本ロボット学会誌, vol.22, no. 5, pp.595-602, 2004.

[3] 岡村, 青山, 田島, 石川, 関, 井上, 糸賀, 清水, 児玉 : “中部国際 空港への清掃ロボット導入”, 第 23 回日本ロボット学会学術講演会 予稿集 CD-ROM, 2005.

[4] 石川, 青山, 田島, 橋ヶ谷, 大石, 三枝: “薬品容器搬送ロボットの開 発”, 第 22 回日本ロボット学会学術講演会予稿集 CD-ROM, 2004.

[ 5 ] 石川, 青山, 田島, 岡村, 橋ヶ谷, 大石, 小幡: “連結式容器搬送ロボッ トの実用化”, 第 23 回日本ロボット学会学術講演会予稿集 CD-ROM, 2005.

[6] 関, 石川, 青山, 和田迫, 薩見, 石村, 西原, 高藤, 零, 伊澤, 橋个 谷, 大石, 小幡, 三枝: “連結式容器搬送ロボットシステムの改良”, 第 25 回日本ロボット学会学術講演会予稿集 CD-ROM, 2007.

[7] 東京都福祉保健局：“医薬品の品質管理について”, http://www. fukushihoken.metro.tokyo.jp/kenkou/iyaku/sonota/license/gkatahe/gqp/index.html

[8] 高橋他：“物流技術のこれから”, 日本機械学会誌, vol.100, no.942, pp.89-95, 1997.

[ 9 ] 斉藤：“工場内物流無人化のための機器活用法”, 自動化技術, vol.29, no.10, pp.10-15, 1997.

[10] 取崎：“搬送システムで無人フォークリフトをどう使うか”，自動化技 術, vol.29, no.10, pp.16-19, 1997.

[11] 石川：“モノレール式無人搬送車をどう使うか”，自動化技術，vol.29, no.10, pp.20-25, 1997.

[12] 坪内：“天井式自動化クレーンをどう使うか”，自動化技術，vol.29， no.10, pp.26-29, 1997.

[13] 小平：“パレタイジングロボットをどう使うか”，自動化技術，vol.29, no.10, pp.30-35, 1997.

[14] 太田 他：“コンベア搭載型 $\mathrm{AGV}$ の協調による物体搬送システム”, 日本機械学会論文集 C 編, vol.67, no.658, pp.209-215, 2000.

[15] 仁野, 三富：“無人搬送車をどう使うか”，自動化技術，vol.29，no.10， pp.36-39, 1997.

[16] 牧野: “SCARA ロボットの設計思想”, 日本機械学会誌, vol.86, no.773, pp.45-50, 1983.

[17] 江口, 薮内, 高木, 乾, 小林：“移動ロボットの直進走行制御と移動 方式”, 第 13 回日本ロボット学会学術講演会予稿集, pp.897-898, 1995.

[18] 清弘, 降矢：“床磨きロボットの自己推進制御（第 3 報)”, 第 12 回 日本ロボット学会学術講演会予稿集, pp.1213-1214, 1994. 


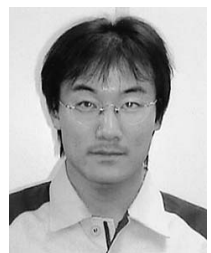

関 淳也（Junya Seki）

2005 年宇都宮大学大学院博士前期課程修了. 同年 富士重工業（株）入社. 現在, 同社戦略本部クリー ンロボット部にて清掃ロボット，搬送ロボット，地 雷探知ロボット等の各種ロボットの研究開発に従事. 日本機械学会の会員。（日本ロボット学会正会員）

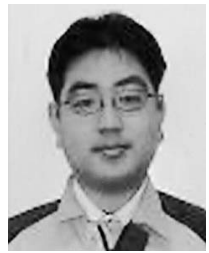

\section{石川和良（Kazuyoshi Ishikawa）}

1999 年明治大学理工学部機械工学科卒業, 同年富士 重工業 (株) 入社. トレーラの構造設計, 清掃ロボッ 卜の開発を担当. 現在同社戦略本部クリーンロボッ 卜部主任として, 清掃ロボット, 搬送ロボット, 地 雷探知ロボット等の各種ロボットの研究開発に従事. 日本機械学会の会員。（日本ロボット学会正会員）

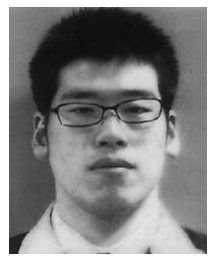

和田迫鉄矢（Tetsuya Wadasako）

2006 年山梨大学大学院博士前期課程修了. 同年富 士重工業 (株) 入社. 現在, 同社戦略本部クリーン ロボット部にて清掃ロボット, 搬送ロボット等の各 種ロボットの研究開発に従事。

(日本ロボット学会正会員)

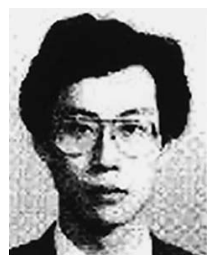

\section{横田和隆（Kazutaka Yokota）}

1987 年東京大学工学部精密機械工学科卒業. 1991 年ロンドン大学インペリアル・カレッジ大学院博士 課程修了. 1992 年宇都宮大学工学部機械システム 工学科助手. 1995 年同学科助教授. 2002 年同大学 工学部附属ものづくり創成工学センター助教授をへ て, 現在同大学大学院工学研究科循環生産研究部門 准教授. Ph.D.. 知能移動ロボット, 不整地移動脚式ロボット, 組立 計画の支援・自動化, 保全作業の自動化などの研究に従事. 日本機械 学会, 精密工学会の会員.

(日本ロボット学会正会員)

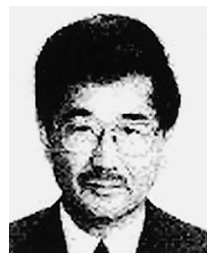

山本純雄（Sumio Yamamoto）

1971 年東北大学大学院工学研究科精密工学専攻博 士課程単位修得退学, 宇都宮大学大学院工学研究科 情報制御システム科学専攻教授, 同大学工学部長な どをへて，現在同大学理事. 工学博士. 感覚・感性 の計測，複合システムの計測制御，群システムなど の研究に従事. 日本機械学会, 環境システム計測制 御学会などの会員.

(日本ロボット学会正会員)

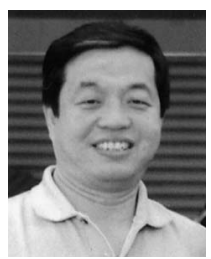

青山 元 (Hajime Aoyama)

1979 年山梨大学工学部精密工学科卒業, 同年, 富 士重工業 (株) 入社. 高所作業車の安定制御装置, 大型多軸自走車の油圧駆動および全輪操舵システ ム，清掃ロボットの開発を担当. 1999 年宇都宮大 学大学院博士後期課程修了. 現在, 同社戦略本部ク リーンロボット部部長として清掃ロボット，搬送ロ ボット, 地雷探知ロボット等の各種ロボットの研究開発に従事. 博士 (工学). 日本機械学会の会員.

（日本ロボット学会正会員）

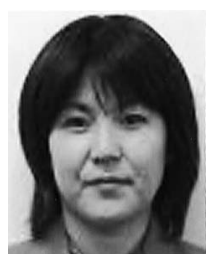

\section{石村左緒里（Saori Ishimura）}

1995 年東京科学電子工業専門学校機械工学科卒業. 現在, 清掃ロボット, 搬送ロボット, 地雷探知ロボッ 卜等の研究開発に従事。（日本ロボット学会正会員）

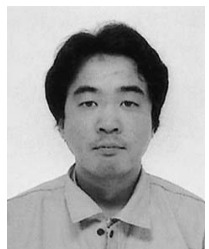

薩見雄一（Yuichi Satsumi）

2003 年第一工業大学航空工学科卒業. 2007 年富士 重工業（株）入社. 現在, 同社戦略本部クリーンロ ボット部にて清掃ロボット, 搬送ロボット, 地雷探 知ロボット等の研究開発に従事.

（日本ロボット学会正会員）

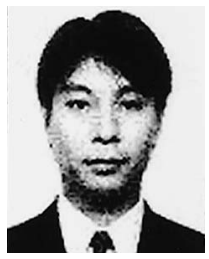

尾崎功一（Koichi Ozaki）

1993 年東洋大学大学院博士前期課程修了. 1995 年 埼玉大学大学院博士後期課程修了. 1995 年理化学 研究所奨励研究員. 1996 年宇都宮大学工学部助手. 1997 年同大学講師. 2002 年宇都宮大学工学研究科 助教授を経て, 現在は同大学工学研究科学際研究部 門准教授. 移動ロボット，および画像計測の応用に 関する研究に従事. 博士 (工学)。日本機械学会, 精密工学会, 環境 システム計測制御学会の会員.

（日本ロボット学会正会員） 